\title{
Crafting Social Change: Former Global Factory Workers Negotiating Identities in Sri Lanka's Villages
}

These village people, they can be nice when they want to, but can turn vicious at any moment. I tread carefully here, at least until I have two, three children and a good economic foundation. Trying in-your-face FTZ mod in these backward villages will not bring us any power. I try to get my way by putting on the sil redde.

Shanika, a former Free Trade Zone (FTZ) worker now residing in her marital home, said this with a laugh. Sil redde is the white shawl worn when observing Buddhist disciplinary principles on poya days. Shanika's comment is interesting at two levels: because as per early nationalist discourses, white signifies purity (De Alwis 1997); and because Shanika was deftly combining this notion with a Buddhist accoutrement (the sil redde) to perform discipline.

While all newly married women devise strategies to endear themselves to in-laws, Sri Lanka's former FTZ workers find doing so more challenging given the stigma attached to their prior employment. Many rural households have daughters or nieces who worked in the FTZs and relatives generally claim these women did so to help their families survive economically. I got quite used to hearing people say their daughter 'was not like all those other garment girls who behave without any shame-fear.' However, almost all mothers had qualms about their sons marrying a FTZ worker.

This article explores how former garment factory workers negotiate new lives and identities after 5-6 years of employment in an urban Free Trade Zone. Most marry a year or two after leaving the FTZ and move to their husbands' villages. Based on ethnographic research 
conducted in their marital homes, this article argues that their performances of self-discipline and disavowal of transgressive FTZ knowledges allow them to make use of the limited social, economic, and political spaces available in these villages and gradually reshape existing gender norms. Indeed, their skillful navigation of cultural expectations is mostly responsible for new social status markers and young women's entry into village civic leadership.

Former FTZ workers have spent many years living in an urban transnational space where predatory men and hedonistic consumer culture are said to corrupt innocent village women (Hewamanne 2008; 2012a; 2016). After leaving the FTZ and getting married, often through parental arrangements, these women find themselves in affinal villages where surveillance mechanisms are more strict for newly married women. Constrained by such rigid social norms, these women, who developed an intense oppositional consciousness during their time in the FTZ, resort to disciplining their bodies, speech, and mannerisms. Although they seemed to retract into their pre-FTZ selves, this article holds that such apparent conformity opens up avenues for economic and social empowerment and gradual social change. The article thus investigates how such deliberate displays of conformity help them use networks developed while in the FTZs to generate income and organize community activities that raise their status within the village. It explores the consequent new understanding of the ideal young, married woman, who is appropriately disciplined and conforming, yet engages in local and trans-local activities that economically benefit her young family while also bringing prestige to her extended family.

This article further argues that there is a simultaneous construction of "lazy lalies" [daughters-in- law] — stay at home moms/wives who are a drain on their families, in contrast to superwoman daughters-in-law who generate money and prestige for their families. Although their activities in the short run seem to affirm patriarchal kinship and power relations, I argue 
that the performance of conformity and disavowing of FTZ transgressions early in their marital homes involve considerable strategizing aimed at changing existing power relations and gender norms and thus rather than being tactical everyday politics, represent strategic political activities that facilitates long term social transformations.

\section{Background/research methods}

When the first FTZ was established in Katunayake in 1978 (and two more subsequently in other areas) the expectation was that unemployed rural women would fill the newly created assemblyline jobs, work for a few years to accumulate money and jewelry for their dowry, and thereafter return to villages and become conventional rural married women. The assumption that such women, lacking alternative choices and being merely supplementary wage earners, would accept employment under any condition resulted in substandard work environments, abysmal living conditions, and minimal wages. As of 2016, the basic FTZ worker salary was rupees 10,000 (about US\$ 85) per month, but women can earn about rupees 18,000 by working overtime and foregoing annual leave.

As in other transnational factories around the world (Fernandez-Kelly 1983; Mills 1999; Freeman 2000; Salzinger 2003; Ngai 2005; Prentice 2016), Katunayake factories demand maximum output for minimal wages in exploitative working conditions and practice a distinctively late capitalist form of gendered working relations. About 80,000 young rural women from economically and socially marginalized groups work as machine operators in the FTZ's 92 factories and a similar number work for subcontracting factories located around the zone (Sri Lanka Board of Investment, n.d). Most are unmarried, young, and well-educated, often with 10-12 years of schooling (Hewamanne 2016). 
Katunayake is located 35 kilometers northeast of Colombo and also contains Sri Lanka's international airport. Most FTZ workers there have migrated from economically stagnant areas in the North Central and Southern Provinces. There are few state or factory-run hostels; instead women mainly make do by renting rows of rooms locals have hastily and poorly built. The physically and mentally arduous working conditions coupled with dreary housing make FTZ life difficult. The sexual harassment workers face on the city's streets only compounds these difficulties (Hewamanne 2008b; 2016).

Yet the workers' status as young women who live alone is what garners the most public attention. So many young women congregating in one place is such an unusual phenomenon that people call the FTZ Sthri Puraya [city of women], Prema Kalape [love zone], and Wesa Kalape [whore zone]. Accounts relating premarital sex, rape, prostitution, abortion, and infanticide portray these women as victims of labor and sexual exploitation and their own loose morals. Intense anxieties about their morality create an image of FTZ workers as loose women who can be easily deceived into sexual relationships. Such stigma attached to their work results in diminished bargaining power within social relationships (Hewamanne 2008; 2017).

Despite these travails of FTZ work outweighing overall gains, a stagnant agricultural economy, lack of alternative employment, and the quest for urban life styles influence women's decisions to migrate. Indeed, cohabiting with other young women while living in an urban area cause workers to undergo social, cultural, emotional, and cognitive changes. For instance, they start to value relative freedom of movement and new lifestyles; they acquire global knowledge flows; and the intense socialization process in factories and boarding houses encourage them to dress, behave, think, and desire in new ways. 
In 2000, I worked in a factory and shared a large boarding house with workers for almost a year. I investigated how they create new identities as a gendered group of migrant workers who differ from other women, other industrial workers, and men. While negotiating difficult lives in transnational factories, I documented how the new forms of political and feminist consciousness they developed helped them easily move among varied identity stances.

Their journey toward becoming, in their word, 'mod' (modern women) was constrained by the realization that they will eventually return to villages. Most FTZ factory owners expect workers to leave after five years and they provide workers with a gratuity payment that supplements their accumulated Employees Provident Fund (EPF) payments, which together is supposed to be used as a dowry. Throughout my research, I found workers contemplating their eventual departure from Katunayake with trepidation. Despite being physically tired, they also dreaded leaving the relative economic and social independence of the FTZ for villages where surveillance regimes are more fully enforced.

This reluctance prompted me to study how they negotiate new lives once back in their villages. Consequently, I have since 2003 investigated how these former workers reintegrate into villages as prospective brides, new wives, and young mothers. During the winters of 2007 and 2008 and summers of 2003-2016 I stayed in 37 selected workers' village homes to examine how they negotiated new lives with the new sense of self and political consciousness acquired in the FTZ. These visits ranged from three days to two weeks, and repeat visits ranged from three to six times. While in the villages, I collected their narratives and interviewed relatives, in-laws, and neighbors. I participated in their gendered social activities and expressive practices (storytelling, joking, singing), and followed them as they engaged in village social and political activities. I first got to know these 37 workers during my research in the Katunayake FTZ and 
kept in touch with most of them via letters and telephone. I visited their villages after repeated invitations. These women, therefore, were not selected according to a recognized sampling method.

While studying this particular group produces an account particular to the group, one must appreciate the advantages that come with studying a group that is willing and inviting. These are women who are familiar enough with me to recount details about their sexual experiences, share erotic jokes about Buddha, and giggle over whispered secrets. In addition, my fluency in Sinhala and their families appreciating me for being an educated woman who had not changed much (in dress and mannerisms) despite traveling to western countries helped in gaining support. Qualitative informed consent was obtained throughout the research period by explaining the research questions and expected outcomes during each visit to workers' homes. While the relationships were hardly equal, they were rooted in warm, intimate and affectionate friendships. Such close relationships can result in certain biases and I have employed deep reflexivity during the research and writing process to emphasize specific contours of knowledge production.

\section{Identities, play and empowerment}

While studies evidence how identities created elsewhere get tested once people return home (Tsuda 2003; Constable 2004; Soco 2008), there is a glaring lacuna on this score when it comes to former global factory workers. Similarly, while the feminization of labor in the global economy has been evaluated, how former workers negotiate new lives once back in their villages remains unaddressed. Some studies also assert that the socio-economic empowerment global factory workers garner is short term (Fernandez-Kelly 1983; Pena 1997). I argue that although 
initially it may seem that way, the early retraction into normative feminine selves can eventually lead to economic empowerment and crucial social changes.

According to Hall, identities should be understood as points of suture or a temporary attachment to already constructed positions. Effective suturing, however, not only requires that the subject be 'hailed'; but it also necessitates the subject to maneuver through other potential positions and choose and invest in these positions (2000: 6). My earlier work traversed through such processes of suturing among FTZ workers and evidenced situational identifications and play that ranged from 'politically conscious, fun-loving mod girls' to 'innocent village girls.'

According to Chela Sandoval (2000), differential consciousness enables movement between and among positions and, in that sense, operates like the 'clutch of an automobile: the mechanism that permits the driver to select, engage and disengage gears in a system for the transmission of power' (14). This capacity is concomitant with developing an oppositional consciousness that confers the ability to read power relations and deliberately choose the most opportune position to challenge power relations. I have earlier used Sandoval's conceptualization of tactical subjectivity to theorize how FTZ working women develop oppositional consciousness and how it facilitates movement among identity stances.

Sandoval's notion of self-conscious subjects, who can freely choose to break away from subject positions, however, disregards how both relations and structures of power impose identities upon subjects. For it is not easy to shift gears between identities when they are set amidst rigid social structures and institutions. FTZ workers excel in such shifts while at the FTZ; but when the very structure of this employment forces them out of their jobs, most have no other option but to return and re-assume their identities as village daughters. Although I agree that one can move fluidly among identity stances, I also hold that there may be obstacles to holding onto 
a favorite identity, and that some identities may have greater propensity towards fixity than others.

Identities such as rural wives and mothers represent more-fixed labels than what these women had available in the FTZs. It is in such circumstances that workers manipulated available resources within given positions. Thus while establishing themselves within a specific identity, they manipulate different forms of capital—savings, networks and cultural knowledge — to create new characteristics under the conventional identity label — such as industriousness and networking abilities for daughters-in law.

Studies have long evidenced how women use family values in the workplace to negotiate male-centered cultures (Lamphere 1985; Sheizer 2005; Hewamanne 2008). According to Ong (1987), Malay FTZ workers embraced an ascetic Islamic persona to counter the extant image of workers being westernized and pleasure seeking (186). The former Sri Lankan FTZ workers' presentation of self seems somewhat similar to this attempt to construct an alternate subjectivity based on a cult of purity (191). The difference is that the Sri Lankan women consciously perform social conformity as a first step toward entering village economic and political spaces.

Several studies on transnational production also demonstrate how women used the veil (Amin 2006; Lindquist 2008) and developed parent-child relationships with bosses (Lynch 2007; Hewamanne 2008) to create better work environments for themselves. My work here addresses the inverse: how former workers use family values and gender norms to facilitate their reincorporation into village life after wage work.

Recent scholarship on collective identities demonstrate how groups and individuals use art, objects, rituals, music, work ethics and language to craft identities that empower and allow political voice (Adams 2006; Rountree 2010; Russell 2011; Hewamanne 2012b, 2016). Several 
studies also focus on how forms of cultural expression hold affective presence with deep emotive/power to mobilize (Adams 2006; Hewamanne 2012b). Building on these studies, I argue that former workers' individual efforts at negotiating favorable identities in their marital homes are highly strategic endeavors that can profoundly change social hierarchies and gender norms.

Scholars have pointed out that political activities must have a collective organizing element to effect transformative politics (Foster 1998; Verma 2005; Mann 2010). Tactics that merely allow people to circumvent dominant power in the short run without the potential for social change therefore get labeled everyday politics (De Certeau 1984; Mayol 1998). How then to label individually executed strategic actions that gradually transform social norms and hierarchies — given that former FTZ workers' strategies of re-incorporation and reputation management lead to such changes? Since a spatial, temporal connection between individual strategies and later changes cannot be easily made, such actions cannot be termed transformative politics. Neither can they be termed everyday politics devoid of strategic planning or transformative values. I therefore contend that their actions promote the conditions of possibility for transformative actions and thus fall in between every day and transformative politics.

The following section highlights several former workers' experiences as they negotiate social and economic life in their communities to showcase how performances of social conformity are imbued with strategic planning that leads to structural change in the long run.

\section{Nisha-she who was in the mud but not of the mud ${ }^{i}$}

'My daughter-in law is one in a million. Her parents have brought her up with good values. Why lie to you? I sometimes wish my daughters were like her. She is obedient, innocent, 
and industrious. She will raise my son to a better place in life.' So said Wimalawathie, motherin-law of former worker Nisha, when I visited their village in Ambilipitiya. Wimalawathie later said she initially had reservations about Nisha. 'Women around here told me stories about badbehaving garment workers, and I have had my doubts. But this girl is like a lotus. You know how our Lord Buddha said the lotus is in the mud but not of the mud. This girl is like that.' It was clear that Wimalawathie and her daughters genuinely admired Nisha, who was among former FTZ workers that negotiated an identity as high-achieving, moral, and disciplined women who worked hard for their families.

Nisha went about her daily chores quickly and cheerfully, mostly due to the new household appliances she brought as part of her dowry. She found time to drop by neighboring households and greeted visitors at home with much warmth. She fell to her knees and paid obeisance to her parents-in-law even when she was going to the grocery store. When male elders were present, she stood leaning against the wall and conversed respectfully. During discussions about the FTZ, she condemned the women who were overly playful and praised the women with whom she had worked and resided with, saying they never forgot why they went to the FTZ: to economically help their families. Her in-laws appreciated these comments, especially when neighbors were present.

Nisha's home business distinguished her from other newly married rural women with the same economic background. While in the FTZ, she attended free workshops on lapidary art at a foreign funded NGO. Once back in the village, she combined her savings and several loans and bought a machine that allowed her to cut gems for a NGO on a contractual basis. This required her to travel to Colombo every two weeks to obtain gems and get paid. This link to Colombo led to people gradually depending on her for small tasks, such as filling a prescription or picking up 
a new clothing item. Nisha said she started helping neighbors out of a sense of charity and to appeal to their generosity of opinion. 'I was scared of rumors. While I am there, I visit boarding houses, friends, shopping centers, and such. I do not want these women to say, "she is dancing with the devil when she goes to Colombo." How could I buy their medicines, ribbons, and buttons, if I didn't visit these places?' She also noted that when she started going to Colombo, she got the work done quickly and then travelled to her aunt's house in Kaduwela to prevent rumors. However, Wimalawathie learned to trust her, so now she stays a night or two with a friend in the FTZ while in Colombo.

In the beginning Wimalawathie objected to Nisha using her electric appliances daily and packaged coconut powder instead of freshly squeezed milk, but as the lapidary work started showing profits, these objections tapered off, allowing Nisha more time for gem-cutting. Although unspoken, both women continually negotiate the challenges and expectations of kinship relations and new economic demands. 'I earn almost half the amount Kasun earns,' Nisha once proudly declared. This fact is not lost on Wimalawathie or the neighbors. 'Many women are now jealous of my lalie. They brought in those princesses born of flowers [sheltered women who were considered more moral] for their sons. Those women just eat and sleep at home, while my lalie brings money home and does all the housework,' Wimalawathie said. Nisha credited Wimalawathie's praise to her carefully following village gender and social norms even when she disagreed with those norms. 'Without your in-law's approval you cannot ever get the support of the community. Without the support of the community you cannot ever be successful in business,' she declared.

\section{Ruwani: we are philanthropists now}


By the time I reconnected with her in 2009, Ruwani had developed a successful village subcontract sewing business. Although Ruwani and her mother-in-law had great rapport, Ruwani was quick to confide that support for economic and civic activities did not come easy. Showing humility, distancing herself from FTZ transgressions, and conforming to expectations regarding the ideal woman at the beginning of her marriage helped win her affinal kin's approval. 'After that, I used their village connections and the good name I built as a good woman to do lots of social service. All this later helped when I started my home business.'

Ruwani and her mother-in-law, Kusum, worked hard at their machines and their income helped them acquire prestige consumer goods that were changing their status in the community's eyes. 'Now everybody wants to be like us,' Kusum said gleefully, while adding that a few months back the chief monk, during his sermon, referred to them as "two courageous women who are an inspiration to all village women.” Such praise was bestowed after they donated rupees 6,000 toward constructing a temple alms hall. 'Only one other family could donate more than us....In fact, Dolewatte people (traditional elite family) only donated 5,000. We are as good as them now, and all because of our lalie,' Kusum proudly declared. Ruwani later added that Dolewatte people tried to demean their donation by mentioning her FTZ past, but since she had renegotiated her village identity as an industrious woman who was uncorrupted by the FTZ the insult failed to gain traction.

Ruwani was also among a growing number of women who took their babies to village organizational meetings. 'I think my girls would be social service workers....they started attending meetings when they were just a few weeks old,' said Ruwani with a laugh. I attended one such meeting that Ruwani led while breast feeding her five month old second child. Although rural women sometimes take their breast feeding babies to work, it is new to see 
women engaging in unpaid social work when they are supposed to be homebound with their infants. Ruwani noted that there was some talk about it at the beginning but because her in-laws fully supported her move the others could not force her out of community activities. 'I tell women that there is no need to fall out of micro credit programs because one cannot attend meetings; just bring the babies and a cloth to cover your breasts, and a pillow to put them to sleep. Since I showed them how easy it is now several others bring their babies too,' Ruwani said. This is another instance where her strategies of winning her in laws' approval led to her economic and social success and then to positive changes for other women as well.

\section{Kumudu: swimming upstream}

Kumudu's attempts to win her in-laws' and community's approval were so extreme that she aroused some ire among other young married women in the village. She had good reason to play an exaggerated version of the ideal wife and daughter in law, because when she was at the FTZ she took a young man named Manju to visit her family after dating him for three weeks. She introduced him to the family and community as the man she would marry. But they broke up right after the visit and during an intense argument Manju said he slept with Kumudu only because a friend bet rupees 1,000 against his taking her virginity. Humiliated publicly, Kumudu moved to a different boardinghouse but kept returning to plead with Manju to marry her-by providing him domestic and sexual services.

When I reconnected with her in 2004 she was married to a younger man and living with his relatives. His parents objected to the marriage due to the unconventional age difference and obvious differences in the couple's outward appearance. (While Kumudu was dark-skinned and looked mature for her age, the man was fair-skinned and looked like a teenager.) Overt display of 
new-bride coyness, extreme obedience and even subservience to her younger husband, and dedication to hard work were the only tricks Kumudu had to bridge these gulfs. By all accounts, she did so with great success. As her mother-in-law so aptly put it, 'This woman works for him like a slave [dasiyak].' Kumudu waited on him diligently and, in addition to cooking, cleaning, washing and ironing his clothes, and shining his shoes, she drew water from the well for his toilet needs. She attended to his parents and elderly grandparents who lived next door in just the same way. She also feigned ignorance of thefun activities and sexual escapades people associated with the FTZ. Although they married after a romantic relationship, she addressed Rasika as 'gentleman' (mahatthaya) and on a few occasions as deiya (god).

Interestingly, both her mother-in-law, co-sister (brother-in-law's wife) and several neighboring women found this subservience to be somewhat ridiculous even while they found it endearing. 'It embarrasses me. She has her reasons to be like that and I am sure Miss knows about that, too. I don't need to act like that. I came here with honor, in a red sari, holding a red bouquet of flowers' ${ }^{\text {ii }}$ Kumudu's co-sister complained. Her in-laws were aware of Manju and the 1,000 rupees bet, which actually caused many to lambaste the men involved and sympathize with Kumudu. Although she was somewhat cruel to Kumudu in the beginning, her mother in law, Kumari, had nothing but praise for Kumudu in 2008. 'Not only is she a good wife and daughterin-law, but a very talented woman. She saved my son from self-destruction when he lost his job and started drinking,' Kumari said.

By 2008 Kumudu had developed a profitable business of ready-made children's clothes. Unlike many others, she did not subcontract for bigger factories but had her own selected names on the labels. Kumudu used her friendship network to procure, for a small fee, cut pieces of garments that were thrown out from FTZ factories to sew children's clothing. Her business was 
thriving with three sewing machines located at a hut attached to the in-laws' kitchen. Kumudu sewed all day, while her mother-in-law, co-sister, and a sister-in-law joined in whenever they could find time. She also had four village women who regularly dropped by to sew or to take cut pieces to their homes to sew. When Rasika lost his job in 2007, Kumudu found him work through her FTZ network.

Even the women who complained about Kumudu's performance of conformity complimented her on kindness, generosity and especially business acumen. Yet, with all her business success, Kumudu still jumped into service mode when Rasika and older in-laws appeared. However, by 2013 there were many younger women working around the house and they picked up most of the work, while Kumudu walked busily around the compound issuing orders and appearing to have a hand in cooking, cleaning, sewing and attending to people.

Kumudu donated generously to community functions. She did not actively seek village civic leadership, due to being busy with her business, but said proudly that many had asked her to run for office. 'I am not an office holder of any society, but even older men listen to my advice on village social activities. Because of my business, now Rasika's family and I have status in the village,' Kumudu said.

Considering that people were aware of her FTZ past, the status Kumudu achieved within her family and community was remarkable. The role her show of extreme humility played in gaining the support of in laws and the community is significant here. No one was more aware of it than Kumudu, who said, 'Even my mother said don't go to his village. She asked me to go to a remote place where no one knows my history. But I was tired of being poor and a nobody and wanted to be economically successful. For that I needed family and village support. In any case as a woman "who lost her way" (losing her virginity and thus her 'good name'), I had no 
bargaining power with him. That's why I decided to jump in the river and swim upstream. I did it well. Now everybody loves me and I can go anywhere, any time and no one would say she is running around wildly.'

The reference to jumping in the river and swimming upstream represented deciding to live with affinal kin and winning family and community support, with the plan of using that support toward economic empowerment. Although Kumudu did not take up civic leadership, she played a significant role convincing the village that women could work hard and succeed. She showed that women need to be mobile and active in public spaces if they are to succeed in business and thus widened the path for future female entrepreneurs.

\section{Kalani: many ways to be good}

Not all efforts at conformity help former workers succeed like the three women described above. Kalani, who married her boyfriend of three years in 1995 and moved to his village in Kalutara, found that disciplining herself and performing rituals of conformity did not always gain approval. 'The more I showed meekness, the more abuse I received,' she said when explaining how her in-laws attempted to control her soldier- husbands' salary he sent from the war zone. A few years and two children later, Kalani started fighting back, and virulent verbal battles erupted between the two neighboring households.

Kalani's strategy was to work relentlessly toward economic and social success. 'Because of my six years in the FTZ, I now have iron strength, and I know I can clash with anyone and get my way' she said. Even during the years her in-laws were antagonistic, she spent her own FTZ savings to cement the outside of her parents-in-law's house and to add two more rooms. She also bought a telephone and a gas stove for the house. 
By 2008, they had built a new, two-story house and bought a van to take their two daughters to school. She attributed their financial success to her husband's hard work and her frugality, and it took several visits for me to gather how she had contributed to their success. She had been loaning small amounts of money, ranging from rupees 1,000 to 15,000 at 10 percent interest to village women. She traveled to Katunayake to obtain brassieres and shoes from a manufacturer, and then went house to house selling them at a profit. Intermittently, she supplied lunch packets to construction parties and made pickles and sweets for local grocery stores. Although she did not have affinal kin support, Kalani managed to deploy several other culturally appropriate avenues to build a good reputation, a pre-requisite for village civic engagement. Proximity of her house to the temple was one such avenue.

The first thing I do in the morning is to sweep the temple plaza and clean the flower tables. The monks could see my kitchen and back yard from their windows, and they know how I work like a slave for my family. I am always the first to suggest temple activities and the one to bear the biggest burden executing them. I know that the chief monk has spoken highly of me and on several occasions advised my mother-in-law to be more appreciative of me.

The connection to the temple and her help to in-laws, despite the tensions, earned her much respect through the years. She also managed to put her husband's army position as a SergeantMajor to good use at a time when the civil war was raging and military personnel were considered war heroes. During 2007-2009, she was the chairperson of the village defense committee and had an identity card from the regional police station to check on suspicious people and vehicles. She had almost weekly meetings with the government agent, the chief 
monk, and other village elite to discuss security. She was also chair of the village ladies society [kulangana samithi], secretary of the funeral help society, and secretary of the samurdhi society. Kalani's account demonstrates the many ways to confrom. She tried to be the demure, retiring new bride and, when that did not work, found other ways to show her allegiance to norms; for example, through her connection to the temple. Armed with the chief monk's verbal character certificate and a marriage certificate to a war hero, she seemed to have conquered all the social and political spaces available in the village. Her account demonstrates the necessity of carefully manipulating both monetary and cultural resources for future success.

At the same time, some strategically conforming women found that there are barriers to economic, social, political success that are hard to overcome. In one case, the woman achieved her mother-in-law's approval only to see her jealous husband thwart her attempts at economic success. Another former worker, Anusha, had to abandon her successful business of raising pigs for meat when neighbors expressed concerns that she was bringing un-Buddhist activities to 'a pure Buddhist village.'

Although four former workers were unsuccessful in entrepreneurial activities despite careful maneuvering of cultural expectations, 29 achieved significant economic and social success by skillfully renegotiating their identities as diligent, good Sinhala Buddhist women who once worked at the FTZ but remained uncorrupted. The following sections discuss their strategies as well as how they were different to non-migrant women of their own age and socioeconomic status.

\section{Sacrificial mothers and the wonderful FTZ}


Former FTZ workers made it easy for villagers to accept the new image of the entrepreneurial married woman by articulating it within the rubric of the 'all-sacrificing wife/mother.' Even Nisha, who had no children at the time, reiterated that her efforts were geared to provide her unborn children a bright future. Kalani perhaps most strongly couched her actions in sacrificial wife/mother rhetoric. As a soldier's wife, she already had many media sources to draw from and draw she did. This focus on their sacrifices and suffering is similar to Phukhtun women's narratives of suffering. According to Benedicte Grima (1985), Phuktun women's tragic aesthetic narratives of tapos allowed them to publicly express the extent of their normative Phuktunness (245). The former workers, however, used narratives of sacrifices in a more pragmatic manner and thus moved fluidly between narratives of suffering and celebration, depending on the audience and the context but always with the intention of promoting their own 'good woman' image.

Most former workers confided that they engage in NGO activities requiring travel for their own pleasure and self-fulfillment as well. While some struggled to verbalize the guilty pleasure they derived from traveling, others viewed it as briefly recapturing the relative freedom they experienced in the FTZ. 'Believe me, I love my family and my role in this community, but if I have the choice of getting my material through mail or traveling to get it, I will choose travel,' Nisha said.

All workers talked about their FTZ experiences in a positive light with younger, unmarried women who visited them in their homes - usually after lunch — to help with household chores. While the elderly women slept in the house, these younger women sat outside and talked, joked, and sang songs while cleaning rice or cutting vegetables. I attended many such gatherings and was surprised at how former workers encouraged nonmigrants to give the FTZ a try. While 
noting how 'some others' might have had trouble, they claimed that their experience was fabulous. Even when I knew otherwise, former workers talked about kind and friendly managers, boarding-house owners, and neighbors. These re-imaginings were clearly constructed for the former workers' own benefit. I see this as an attempt to open up restrictive spaces, so they could work toward their economic and political ideals. Even for workers who seem to have made it, like Nisha or Ruwani, strengthening their negotiated positions and widening their narrow avenues represent an everyday struggle that requires creating and maintaining self-narratives that omit anything unacceptable or shameful.

Such strategies made it difficult for people to condemn them outright. Yet, jealousy sometimes resulted in surreptitious talk. A non-migrant married woman once told me that 'Nisha lost shame-fear in the FTZ and therefore is capable of doing anything in Colombo.' In fact most former FTZ workers said that they feared the villagers might at any time invoke their FTZ past to shame and put them in their place. Several former workers sought to have a baby immediately, so as to lessen the stigma of their past. Shanika, who worked closely with the village family health officer, declined to speak to village women about contraceptives in a more official capacity. She explained that she did not want to give them any reason to bring up her FTZ past and to say she is a corrupting influence. Anxieties about village surveillance mechanisms homing in on their FTZ past prompt former workers to carefully balance their entrepreneurial and social activities with a show of humility.

Thus their achievements seem to require 'double duty,' as winning approval means being extra-diligent in household and community obligations. On the other hand, economic success also wins these women a supportive female community that helps to ease their home duties. 
Many high-achieving former workers had groups of female followers who visited frequently and helped with household chores.

The more a woman evidences allegiance to her normative role, the more help she receives from her in-laws and neighbors. Once when I was about to leave after a three-day visit, Nisha's mother-in-law asked her to go to Colombo with me as I was using a hired van. Nisha refused, saying that she had soaked the curtains and has to prepare the the next day's lunch. A little game of persuasion and reluctance ensued, with Wimalawathie offering to do the washing and cooking and Nisha reminding her that the curtains would be too heavy for her, and waking up at dawn was not good for her sinus problems. Each of these reasons was met with gentle but firm reminders that the older woman had done such work alone before. Even after getting dressed, Nisha started dragging her feet because Kasun, her husband, was not at home.

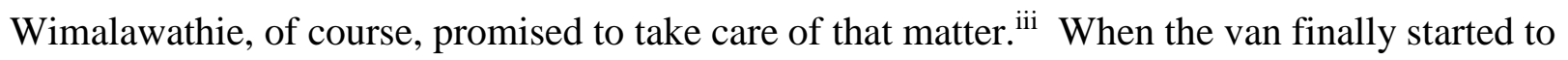
move away, both Nisha and I started giggling for what seemed like a long time.

\section{Lazy lalies and super women lalies}

Most newly married, non-migrant women did not engage in income-generating activities, as opposed to only four of the 37 former workers. The non-migrant women I talked to were selected because their socio-economic backgrounds were similar to those of the former workers I studied in the same villages. Although their family income was enough to afford simple lives without falling into substantial debt, many non-migrant women expressed varying levels of desire to engage in meaningful economic activity.

These women, however, found that they were not able to start sustainable incomegenerating activities without the kind of networking that former workers were exposed to within 
the FTZ. After trying and failing or being discouraged by others' failures, some of the nonmigrant women began using 'respectable woman' vocabulary to cope. As Samitha said, 'a woman's job is to make a good home for her family, not to run around cities with all sorts of people. Although we are poor, we remain respectable, unlike those hussies.'

The economic success of many former workers and their enhanced performance of domestic duties due to their electric appliances and supportive female relatives have initiated a counter-narrative about lazy lalies who are a drain on their young families. As Wimalawathie, in praising how quickly Nisha gets her household work done, said: 'I once visited a house, and one of those lazy girls (nonmigrant daughters-in-law) took close to one hour to get a cup of tea prepared. Her mother-in law was very ashamed. I was thinking, once a lazy girl, always a lazy girl,' implying that women who never left for FTZ work were lazy to begin with.

While I certainly met young, nonmigrant women who seemed lazy, many seemed frustrated with the lack of opportunities for work in their villages. Many had young children at home and found amassing the capital to start a business difficult. Some had been helping their family enterprises but did not get any direct payment or credit for their work. When tempers flared, many had to bear caustic remarks about 'lazy people, who are only one more mouth to feed in the household.'

My mother-in-law always says why can't you be like so and so, which always happen to be those FTZ girls. She wouldn't have approved of me marrying her son if I worked at the FTZ, but she crows about how industrious those women are. She thinks I am lazy and unmotivated,'

Malika once said. Many villagers overlooked how the FTZ interlude had provided former workers with monetary capital and social networks, thus attributing their entrepreneurial success 
to their individual diligence and industriousness. Conversely, the non-migrant women who could not succeed in developing a small business were considered lazy. Malika's mother-in-law once told me that due to modern ways, raising children is not difficult like in the past and thus women should be able to supplement household income through home businesses. Then she provided a few examples that included several former workers. This was a sentiment that many older women echoed.

\section{Conclusion}

Naila Kabeer $(2011,2016)$ has noted that women's paid work is instrumental in poverty reduction, human development and economic growth and that it has the potential to transform their lives. She also holds that these positive outcomes are only possible if paid work empowers women to exercise voice and influence in the key domains of their lives. This article evaluates how women's paid work in FTZ factories has allowed them to engage not just in economic activities but also village socio-political activities (and even involvement at times in regional cities).

When asked to list the most successful women entrepreneurs in their villages, all 37 village agents listed former FTZ workers. In 29 villages the former workers comprised $100 \%$ of the list. Not only had these women achieved economic success, they were building on their accomplishments to make inroads into arenas previously monopolized by male and elderly, middle class women. What makes the Sri Lankan case unique is that most of their successes were so squarely connected to their years working at an urban FTZ. Their FTZ savings and the entrepreneurial spirit they developed while at the FTZ, together with their own careful navigation of gender and kinship norms, were responsible for their success. 
Moreover, connections with and knowledge about the capital city and some urban and international NGOs, and the familiarity with impression and stigma management developed at the FTZ, contribute to economic and social success at the village level. ${ }^{\text {iv }}$ Their skillful negotiation of stigmatized identities once in their in-laws' villages lead to village social capital, which they then combine with their accumulated FTZ social capital. This is what distinguishes these successful former workers from their non-migrant village counterparts who share the same educational and socio-economic backgrounds. ${ }^{\mathrm{v}}$

Sri Lankan villages are in the midst of an intense struggle between an encroaching market economy and the pressure to hold onto traditional values, and this requires women to maneuver respectability, work, and travel in creative ways. In this environment, a woman who could engage in income-generating activities without divorcing herself from the responsibilities of a good woman and articulate these activities under the rubric of sacrificing wife/mother earned an acceptable, even envied position, in her village. Since they themselves confirmed that their initial performances were designed to ensure subsequent socio-economic empowerment, it is important to recognize that seemingly mundane everyday politics, despite being enacted individually, can result in social transformations. Former workers' actions thus represent a form of politics that is in between every day and transformative politics.

The way rural women strategize limited resources with a view to entering social political economic life showcases how marginalized groups manipulate, stretch, and adjust dominant ideals in ways that are meaningful to them. This article has offered glimpses into the ways in which young Sri Lankan women and their communities attempt to reconcile the opportunities created by transnational processes with deeply held notions of the ideal woman. Undoubtedly, 
this space is filled with tension, and open to ever-changing, malleable interpretations of what it is to be a good woman, daughter-in-law, wife, and mother. 


\section{References:}

Adams, Kathleen. 2006. Art as Politics; Re-crafling Identities, Tourism, and Power in Tana Toraja, Indonesia. Honolulu: University of Hawai'i Press.

Amin, Sajeda. 2006. “Implications of Trade Liberalization for Working Women's Marriage:

Case Studies of Bangladesh, Egypt and Vietnam.” In Trading Women's Health and Rights?

Trade Liberalization and Reproductive Health in Developing Economies, edited by Caren Brown, Elissa Braunstein and Anju Malhotra eds. London: Zed.

Constable, Nicole. 2004. "Changing Filipina Identities and Ambivalent Returns.” In Coming Home?: Refugees, Migrants, and Those Who Stayed Behind, edited by Lynellyn D. Long and Ellen Oxfeld, 104-24. Philadelphia: University of Pennsylvania Press.

De Alwis, Malathie. 1997. “The Production and Embodiment of Respectability: Gendered Demeanors in Colonial Ceylon.” In Sri Lanka Collective Identities Revisited, edited by Michael Roberts. Colombo: Marga Institute.

De Certeau, M. 1988. The Practice of Everyday Life. Berkeley: University of California Press.

Fernandez-Kelly, Maria Patricia. 1983. For We Are Sold, I And My People. Albany: SUNY Press. Foster, Sheila. 1998. "Justice from the Ground up: Distributive Inequities, Grassroots Resistance, and the Transformative Politics of the Environmental Justice Movement." California Law Review 86 (4): 775-841.

Freeman, Carla. 2000. High Tech and High Heels in the Global Economy: Women, Work, and Pink-Collar Identities in the Caribbean. Durham: Duke University Press.

Grima, Benedicte. 1985. "The Pukhtun Tapos: From Biography to Autobiography.” Asian Folklore Studies 44: 241-267. 
Hall, Stuart. 2000. “Introduction.” In Questions of Cultural Identity, edited by Stuart Hall and Paul DuGay. London: Sage.

Hewamanne, Sandya. 2008. "Stitching Identities in a Free Trade Zone: Gender and Politics in Sri Lanka. Philadelphia: University of Pennsylvania Press.

Hewamanne, Sandya. 2012. “Threading Meaningful Lives: Respectability, Home Businesses and Identity Negotiations among Newly Immigrant South Asian Women.” Identities 19 (3): 320338.

Hewamanne, Sandya. 2012. "Negotiating Sexual Meanings: Global Discourses, Local Practices and Free Trade Zone Workers on City Streets.” Ethnography, 13 (3):352-374.

Hewamanne, Sandya. 2016. Sri Lanka's Global Factory Workers: (Un)Disciplined Desires and Sexual Struggles in a Post-Colonial Society. London: Routledge

Hewamanne, Sandya. 2016. “A Buddha in the Making: Maniyo.” In Figures of Buddhist Modernity in Asia, edited by Jeffrey Samuels, Justin McDaniel and Mark Rowe. Honolulu: University of Hawaii Press.

Hewamanne, Sandya. 2017. "Health and Safety for Ten Hours Plus: Why CSR Policies are Not Successful as Envisioned," In Unmaking the Global Sweatshop: Health and Safety of the World's Garment Workers. Edited by Geert De Neve and Rebecca Prentice. Philadelphia: University of Pennsylvania Press.

Kabeer, Naila. 2011. Contextualising the Economic Pathways of Women's Empowerment:

Findings from a Multi Country Research. Pathways Policy Paper. Brighton: Pathways of Women's Empowerment RPC.

Kabeer, Naila. 2016. "Economic Pathways to Empowerment and Active Citizenship: What does the Data from Bangladesh Tell us?” The Journal of Development Studies 53(5): 649-663. 
Lamphere, Louise. 1985. "Bringing the Family to Work: Women's Culture on the Shop Floor." Feminist Studies 11(3):519-540.

Lindquist, Johan. 2008. The Anxieties of Mobility: Migration and Tourism in the Indonesian Borderlands. Honolulu: University of Hawai' $i$ Press.

Lynch, Caitrin. 2007. Juki Girls, Good Girls: Gender and Cultural Politics in Sri Lanka's Global Garment Industry. Ithaca: Cornel University Press.

Mann, Eric. 2010. “Transformative Organizing.” Race, Poverty \& the Environment 17 (2): 8487.

Mayol, Pierre. 1998. "Living." In The Practice of Everyday life, edited by M. De Certeau, L.Giard and P. Mayol. Minneapolis: University of Minnesota Press.

Mills, Mary Beth. 1999. Thai Women in the Global Labor Force: Consuming Desires: Contesed Selves. New Brunswick: Rutgers University Press.

Ngai, Pun. 2005. Made in China: Women Factory Workers in a Global Workplace. Durham: Duke University Press. Ong, Aihwa. 1987. Spirits of Resistance and Capitalist Discipline: Factory Women in Malaysia. Albany: State University of New York Press.

Pena, Devon. 1997. The Terror of the Machine: Technology, Work, Gender and Ecology on the U.S.-Mexico Border. Austin: University of Texas.

Prentice, Rebecca. 2016. Thiefing a Chance: Factory Work, Illicit Labor, and Neoliberal Subjectivities in Trinidad. Boulder: University of Colorado Press.

Rountree, Kathryn. 2010. Crafting Contemporary Pagan Identities in a Catholic Society. London: Ashgate.

Russell, Tiffany. 2011. "Pear Trees and Poetry: Crafting Identity in a Private Boarding School." Black Women, Gender + Families 5 (2): 93-115. 
Salzinger, Leslie. 2003. Genders in Production: Making Workers in Mexico's Global Factories. Berkley: University of California Press.

Sandoval, Chela. 2000. Methodology of the Oppressed. Minneapolis: University of Minnesota Press.

Seizer, Susan. 2005. Stigmas of the Tamil Stage: An Ethnography of Special Drama Artists in South India. Durham: Duke University Press.

Soco, Andrea. 2008. "Changing the Discourse on Return Migrants: Cosmopolitanism and the Reintegration of Return Filipino Migrant Domestic Workers.” Philippine Sociological Review 56:1-19.

Tsuda, Takeyuki. 2003. "Domesticating the Immigrant Other: Japanese Media Images of Nikkejin Return Migrants.” Ethnology 42 (4): 289-305.

Verma, A. K. 2005. "Backward Caste Politics in Uttar Pradesh." Economic and Political Weekly 40 (36): 3889-3892.

\footnotetext{
${ }^{\mathrm{i}}$ All individual names are pseudonyms. Village names have also being changed to protect confidentiality. I use actual regional city names throughout the article, but these cities are big enough to not endanger confidentiality.

ii An honor accorded to women who proved their virginity after marriage.

iii In almost all cases, there was a somewhat distant but tender relationship between fathers-inlaw and daughters-in-law. Most husbands also let their mothers and wives come to an agreement on home and outside work while displaying varying levels of support for their wives' entrepreneurial activities.

iv I am analyzing their entrepreneurial success and civic leadership in detail in another publication.
} 
" Kabeer (2011) further notes the importance of taking the men's role in strengthening or hindering women's empowerment. All 37 women interestingly had non-abusive, more or less non-involved and more or less verbally supportive husbands, fathers and fathers-in-law. Interestingly all the non-migrant women except one that I interviewed also had non-abusive husbands. It also came to light that their parents' cultural concerns, more than their own lack of enthusiasm, prevented them from migrating for FTZ work in the first place. 